\title{
Effects of exogenous glucose on glucose metabolism in the lactating goat in vivo
}

\author{
By N. CHAIYABUTR, ANNE FAULKNER AND M. PEAKER \\ Hannah Research Institute, Ayr KA6 5HL, Scotland
}

(Received 18 March 1982 - Accepted 7 September 1982)

\begin{abstract}
1. Glucose turnover in fed and $48 \mathrm{~h}$-starved lactating goats was determined during a glucose load of $500 \mu \mathrm{mol} / \mathrm{min}$ using a continuous infusion of $\left[\mathrm{U}-1{ }^{19} \mathrm{C}\right]-$ and $\left[3-{ }^{3} \mathrm{H}\right] \mathrm{glucose}$.

2. Endogenous rates of irreversible glucose turnover (i.e. total rates of irreversible glucose turnover minus the rate of exogenous glucose supply) were depressed during glucose loading by 14 and $62 \%$ in the fed and starved animals respectively.

3. Plasma glucose concentrations increased significantly by 57 and $88 \%$ in the fed and starved goats respectively. Plasma insulin concentrations increased by 108 and $128 \%$ in the fed and starved animals respectively.

4. Milk yields increased significantly $(41 \%)$ in the starved animals during glucose loading, but were unaffected in fed animals.

5. In both the fed and $48 \mathrm{~h}$-starved goats, mammary glucose metabolism via glycolysis and the pentose phosphate pathway appeared to be stimulated by glucose loading.
\end{abstract}

The provision of glucose for the ruminant is almost entirely by gluconeogenesis in the liver and kidney (Bergman, 1973). There is argument whether glucose availability may limit milk production during lactation, when there is a large requirement for glucose. Although glucose supply might be rate-limiting at low blood glucose concentrations, there is little evidence for glucose limitation in normoglycaemic goats and cows (see Rook, 1979). In two goats a positive response of milk secretion to glucose infusion appears to have been obtained (Linzell, 1967; Mepham \& Linzell, 1974). However, as in both instances the goats were milked every hour, which may itself stimulate secretion (Linzell \& Peaker, 1971; Blatchford \& Peaker, 1982), interpretation is difficult. Moreover, in the work of Linzell (1967) the goats had a low blood glucose concentration.

In starved lactating ruminants, which have reduced rates of glucose synthesis, the rate of milk secretion falls (Annison et al. 1968; Reid et al. 1977).

In order to study both the regulation of glucose synthesis and the effect of exogenous glucose on milk production and mammary metabolism we infused glucose into fed and $48 \mathrm{~h}$-starved lactating goats for a period of $4 \mathrm{~h}$, and followed the changes in glucose metabolism in the whole animal and in the mammary gland.

\section{MATERIALS AND METHODS}

\section{Goats}

The experiments were conducted on lactating British-Saanen goats aged 3-10 years (6-14 weeks post partum) and weighing 40-60 kg. The animals were surgically prepared for the collection of mammary-venous and -arterial blood (Linzell, 1960) and were accustomed to their surroundings before experimentation. Animals were given hay ad lib. (approximately $1.2 \mathrm{~kg} / \mathrm{d} ; 85 \%$ dry matter, $10 \%$ crude protein, $7520 \mathrm{~kJ} / \mathrm{kg}$ metabolizable energy), which was available throughout the day, and concentrates $(1500 \mathrm{~g} / \mathrm{d} ; 4.75 \%$ oil, $16 \%$ protein, $9 \%$ fibre, $10240 \mathrm{~kJ} / \mathrm{kg}$ metabolizable energy) which were provided at the times of milking (08.00 and 16.00 hours). 


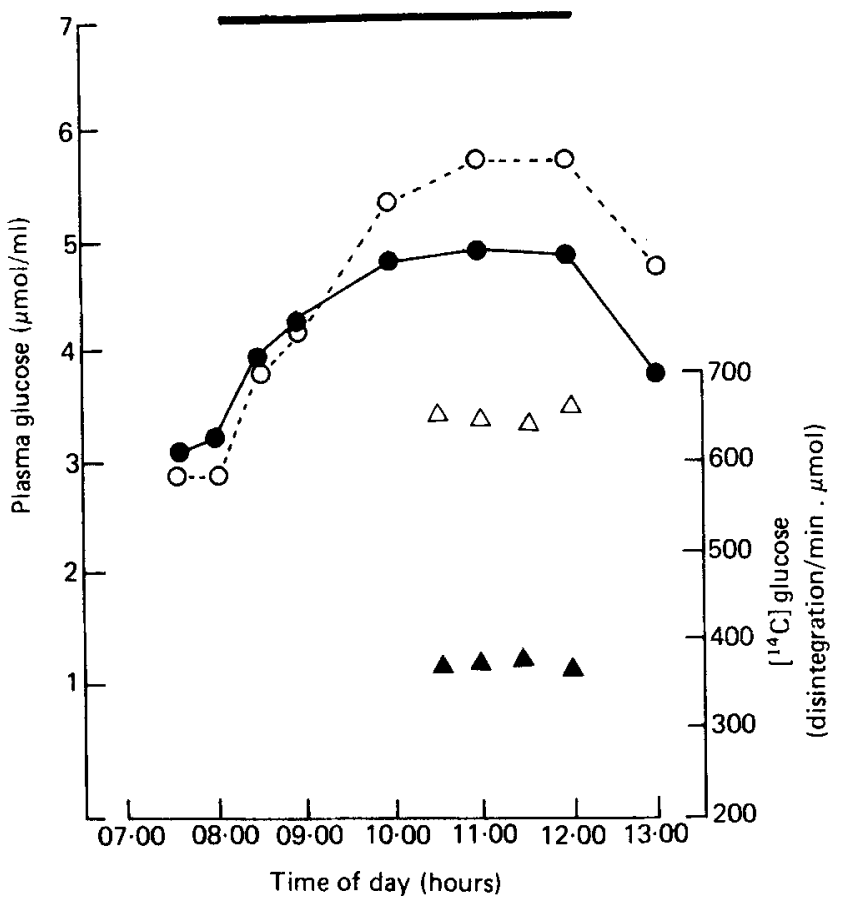

Fig. 1. Changes in the mean concentrations $(\odot, O)$ and specific activities $(\triangle, \Delta)$ of plasma glucose in the fed $(0, \Delta)$ and $48 \mathrm{~h}$-starved $(\mathrm{O}, \triangle)$ lactating goat. Bar, period of glucose infusion.

\section{Chemicals}

Radioactive compounds were obtained from Amersham International, Amersham, Bucks; all enzymes and coenzymes were obtained from Boehringer Corporation (London), Lewes, East Sussex and Sigma, Poole, Dorset. All other chemicals were obtained from British Drug Houses, Poole, Dorset.

\section{Methods}

On the day before the experiment catheters were placed in a jugular vein, the exteriorized carotid artery and subcutaneous abdominal vein. At approximately 08.00 hours a priming dose of radioactive glucose $\left(5 \mu \mathrm{Ci}\left[3^{-3} \mathrm{H}\right]\right.$ glucose, $3 \mu \mathrm{Ci}$ [U- $\left.{ }^{14} \mathrm{C}\right]$ glucose $)$ in sterile saline $(9 \mathrm{~g}$ sodium chloride/l) was injected into the jugular vein followed by an infusion of $0.4 \mu \mathrm{Ci}$ $\left[3-{ }^{3} \mathrm{H}\right]$ glucose $/ \mathrm{min}, 0 \cdot 2 \mu \mathrm{Ci}\left[\mathrm{U}-{ }^{14} \mathrm{C}\right]$ glucose $/ \mathrm{min}$ and $500 \mu \mathrm{mol}$ non-radioactive glucose $/ \mathrm{min}$, which continued for $4 \mathrm{~h}$. Infusions into a separate group of control animals which were at the same stage of lactation and giving similar milk yields contained no non-radioactive glucose. This procedure produced a constant specific activity and concentration of plasma glucose throughout the final $1 \mathrm{~h}$ of infusion (Fig. 1). During the final $1 \mathrm{~h}$, blood samples were taken from the carotid artery and subcutaneous abdominal vein. The same group of five animals was used for the glucose infusions into both the fed and starved goats. The starved experiments were always performed after the fed experiments (usually with about a week's interval to allow the radioactivity to be cleared from the bloodstream). A second group of six animals was used for the fed and starved control experiments. In addition, results were available from five different starved goats and these were included with the results from the starved control group. 
Table 1. Effects of glucose infusion on glucose metabolism in fed and 48 h-starved lactating goats

(Mean values with their standard errors; no. of animals in parentheses)

\begin{tabular}{|c|c|c|c|c|c|c|c|c|}
\hline & \multicolumn{4}{|c|}{ Fed } & \multicolumn{4}{|c|}{48 h-starved } \\
\hline & \multicolumn{2}{|c|}{ Control (6) } & \multicolumn{2}{|c|}{ Glucose infused (5) } & \multicolumn{2}{|c|}{ Control (11) } & \multicolumn{2}{|c|}{ Glucose infused (5) } \\
\hline & Mean & $\mathrm{SE}$ & Mean & $\mathbf{S E}$ & Mean & SE & Mean & SE \\
\hline $\begin{array}{l}\text { Endogenous irreversible } \\
\text { glucose turnover using } \\
{\left[\mathrm{U}^{14} \mathrm{C}\right] \mathrm{glucose}(\mu \mathrm{mol} / \mathrm{min})}\end{array}$ & 819 & 79 & 696 & 75 & 341 & 21 & 128 & $106^{*}$ \\
\hline $\begin{array}{l}\text { Endogenous reversible } \\
\text { glucose turnover using } \\
{\left[{ }^{3}{ }^{3} \mathrm{H}\right] \text { glucose }(\mu \mathrm{mol} / \mathrm{min})}\end{array}$ & 929 & 17 & 846 & 79 & 442 & 33 & 281 & 123 \\
\hline $\begin{array}{l}\text { Recycling of } \\
\text { glucose-C }(\%)\end{array}$ & 10 & 3 & $11 \cdot 3$ & $1 \cdot 5$ & 22 & 2 & 20 & $2 \cdot 4$ \\
\hline $\begin{array}{l}\text { Arterial plasma } \\
\text { glucose }(\mu \mathrm{mol} / \mathrm{ml})\end{array}$ & $3 \cdot 1$ & $0 \cdot 3$ & $4 \cdot 8$ & $0.5^{*}$ & $2 \cdot 9$ & $0 \cdot 2$ & $5 \cdot 6$ & $0 \cdot 6^{* * *}$ \\
\hline $\begin{array}{l}\text { Arterial plasma } \\
\text { insulin }(\mathrm{ng} / \mathrm{ml})\end{array}$ & $0 \cdot 37$ & 0.03 & 0.77 & $0 \cdot 22^{*}$ & 0.25 & 0.02 & 0.57 & $0.07^{*}$ \\
\hline
\end{tabular}

Values for the glucose-infused goats which were significantly different from those for the corresponding control animals: ${ }^{*} P<0.05, * * * P<0.001$.

Blood flow through the mammary gland, concentrations of blood and milk constituents and radioactivity in blood and milk constituents were determined as described previously (Chaiyabutr et al. 1980, 1982). Calculations of glucose turnover, recycling and transfer to milk constituents were performed as described previously (Chaiyabutr et al. 1980, 1982).

\section{Statistics}

Values were compared using Student's $t$ test for unpaired observations and are presented as means \pm SEM.

\section{RESULTS}

Effects of glucose infusion on glucose metabolism in the whole animal

Infusion of exogenous glucose $(500 \mu \mathrm{mol} / \mathrm{min})$ into fed and $48 \mathrm{~h}$-starved lactating goats resulted in a decrease in the mean rate of endogenous irreversible glucose turnover, although the decrease was significant only in the starved animals (Table 1). Recycling of glucose-C calculated as a percentage of total glucose turnover (endogenous + exogenous) was unaffected by glucose infusion. Plasma glucose concentrations were significantly elevated during glucose infusion in both the fed and starved goats although the increase was more pronounced in the starved animals (Table 1). Plasma insulin concentrations were also significantly elevated during glucose infusion (Table 1).

\section{Effects of glucose infusion on milk production and mammary metabolism}

In the fed lactating goat, increasing glucose availability by infusing glucose $(500 \mu \mathrm{mol} / \mathrm{min})$ $2 \mathrm{~h}$ after the morning feed had no effect on milk production, mammary glucose uptake or blood flow (Table 2). However, in the $48 \mathrm{~h}$-starved lactating goat, glucose infusion increased milk yields significantly (from $0.34 \pm 0.11 \mathrm{ml} / \mathrm{min}$ to $0.44 \pm 0.03 \mathrm{ml} / \mathrm{min}$ in the glucoseinfused animals pre- and post-infusion) and there were also significant increases in the rate 
Table 2. Mammary blood flow, metabolism and milk yield in fed and 48 h-starved lactating goats infused with glucose

(Mean values with their standard errors; no. of animals in parentheses)

\begin{tabular}{|c|c|c|c|c|c|c|c|c|}
\hline & \multicolumn{4}{|c|}{ Fed } & \multicolumn{4}{|c|}{$48 \mathrm{~h}$-starved } \\
\hline & \multicolumn{2}{|c|}{ Control (6) } & \multicolumn{2}{|c|}{ Glucose infused (5) } & \multicolumn{2}{|c|}{ Control (11) } & \multicolumn{2}{|c|}{ Glucose infused (5) } \\
\hline & Mean & SE & Mean & $\mathrm{SE}$ & Mean & SE & Mean & SE \\
\hline Mammary blood flow ( $\mathrm{ml} / \mathrm{min}$ ) & 470 & 15 & 418 & 37 & 177 & 17 & 201 & 18 \\
\hline $\begin{array}{l}\text { Glucose uptake by the } \\
\text { mammary gland }(\mu \mathrm{mol} / \mathrm{min})\end{array}$ & 363 & 63 & 354 & 56 & 75 & 11 & 106 & 20 \\
\hline $\begin{array}{l}\text { Milk yield }(\mathrm{ml} / \mathrm{min}) \\
\text { Rate of synthesis of }(u \mathrm{~mol} / \mathrm{min})\end{array}$ & 1.07 & 0.08 & $1 \cdot 07$ & 0.04 & $0 \cdot 31$ & 0.02 & $0 \cdot 44$ & $0.03^{* *}$ \\
\hline 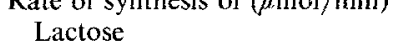 & 148 & 15 & 150 & 5 & 31 & 2 & 57 & $4^{* *}$ \\
\hline Triacylglycerol & 51 & 6 & 54 & 4 & 23 & 2 & 23 & 3 \\
\hline Citrate & $7 \cdot 1$ & $1 \cdot 0$ & 6.7 & 0.5 & $2 \cdot 2$ & $0 \cdot 3$ & $3 \cdot 7$ & $0 \cdot 3^{* *}$ \\
\hline
\end{tabular}

Values for the glucose-infused goats which were significantly different from those for the corresponding control animals: $* P<0.05, * * P<0.01$.

Table 3. Utilization of radioactive glucose in the mammary gland of the fed and $48 \mathrm{~h}$ starved lactating goat during glucose infusion

(Mean values with their standard errors; no. of animals in parentheses)

\begin{tabular}{|c|c|c|c|c|c|c|c|c|}
\hline & \multicolumn{4}{|c|}{ Fed } & \multicolumn{4}{|c|}{$48 \mathrm{~h}$-starved } \\
\hline & \multicolumn{2}{|c|}{ Control (6) } & \multicolumn{2}{|c|}{ Glucose infused (5) } & \multicolumn{2}{|c|}{ Control (11) } & \multicolumn{2}{|c|}{ Glucose infused (5) } \\
\hline & Mean & $\mathrm{SE}$ & Mean & $\mathrm{SE}$ & Mean & SE & Mean & SE \\
\hline \multicolumn{9}{|c|}{$\begin{array}{l}{\left[\mathrm{U}-{ }^{14} \mathrm{C}\right] \text { glucose incorporated }} \\
(\mu \mathrm{mol} / \mathrm{min}) \text { into: }\end{array}$} \\
\hline Milk lactose & 243 & 49 & 258 & 17 & 57 & 6 & 93 & $8 * * *$ \\
\hline Milk citrate & $1 \cdot 5$ & $0 \cdot 2$ & 6.8 & $0 \cdot 8^{* *}$ & $1 \cdot 1$ & $0 \cdot 2$ & $3 \cdot 2$ & $0 \cdot 2^{* *}$ \\
\hline $\begin{array}{l}\text { Mammary-venous } \\
\text { carbon dioxide }\end{array}$ & $12 \cdot 6$ & $1 \cdot 5$ & $34 \cdot 2$ & $7 \cdot 5^{*}$ & $3 \cdot 1$ & $1 \cdot 1$ & $11 \cdot 0$ & $2 \cdot 6^{* *}$ \\
\hline $\begin{array}{l}{\left[\mathrm{U}_{-14}^{14} \mathrm{C}\right] \mathrm{glucose} \text { in milk }} \\
\text { triacylglycerol } \\
(\mu \mathrm{mol} / \mathrm{g} \text { milk fat })\end{array}$ & 162 & 25 & 257 & $17^{*}$ & 122 & 14 & 220 & $33^{*}$ \\
\hline $\begin{array}{l}{\left[3-{ }^{3} \mathrm{H}\right] \text { glucose in milk }} \\
\text { triacylglycerol } \\
(\mu \mathrm{mol} / \mathrm{g} \text { milk fat }\end{array}$ & 897 & 144 & 1457 & 180 & 74 & 12 & 178 & $35^{* *}$ \\
\hline $\begin{array}{l}\text { Rate of milk fat } \\
\text { production }(\mathrm{mg} / \mathrm{min})\end{array}$ & $47 \cdot 5$ & $2 \cdot 3$ & $44 \cdot 5$ & $3 \cdot 1$ & $1 \mathrm{c} \cdot 1$ & $1 \cdot 4$ & $20 \cdot 2$ & $1 \cdot 3$ \\
\hline
\end{tabular}

Values for the glucose-infused goats which were significantly different from those for the corresponding control animals: * $P<0.05,{ }^{* *} P<0 \cdot 01,{ }^{* * *} P<0 \cdot 001$.

of production of lactose and citrate. There was no statistically significant increase in mammary blood flow, arterio-venous difference or uptake of glucose in the starved animals during glucose infusion, but the mean values were slightly elevated (Table 2).

In both the fed and $48 \mathrm{~h}$-starved goats, glucose infusion resulted in a significant increase in the incorporation of glucose- $\mathrm{C}$ into mammary-venous carbon dioxide, milk citrate and the glycerol moiety of milk fat (Table 3 ). In the starved animals there was also a significant 
increase in the incorporation of glucose- $\mathrm{C}$ into milk lactose which corresponded to the increased rate of lactose synthesis (Tables 2 and 3). There was no significant change in the specific activity of $\left[{ }^{14} \mathrm{C}\right]$ lactose during glucose infusion. ${ }^{3} \mathrm{H}$ was also incorporated from $\left[3-{ }^{3} \mathrm{H}\right]$ glucose into milk lactose, but ${ }^{3} \mathrm{H}:{ }^{14} \mathrm{C}$ differed in the glucose and galactose moiety. The ratio in the glucose moiety was the same as that in plasma glucose. In the fed animals glucose infusion had no significant effect on this ratio: ${ }^{3} \mathrm{H}:{ }^{14} \mathrm{C}$ in the galactose moiety was $0 \cdot 70 \pm 0 \cdot 1(n 6)$ and $0 \cdot 64 \pm 0.06(n 5)$ relative to that of plasma glucose in the control and glucose-infused goats respectively. In contrast, glucose infusion into $48 \mathrm{~h}$-starved animals resulted in a significant increase $(P<0.05)$ in ${ }^{3} \mathrm{H}:{ }^{14} \mathrm{C}$ in the galactose moiety from $0.79 \pm 0.04(n 11)$ in controls to $0.98 \pm 0.10(n 5)$ in the glucose-infused goats. This increase in ${ }^{3} \mathrm{H}:{ }^{14} \mathrm{C}$ indicates a reduced rate of recycling of glucose-6-phosphate in the mammary gland of the starved goats during glucose infusion (Chaiyabutr et al. 1980). The reason for this decrease in recycling is unclear but may be related to the increased glucose availability during glucose loading.

${ }^{3} \mathrm{H}$ from $\left[3-{ }^{3} \mathrm{H}\right]$ glucose was also incorporated into milk fat (predominantly into fatty acids of milk fat, see Chaiyabutr et al. 1980) and the amount incorporated increased during glucose infusion, although the increase was statistically significant in the $48 \mathrm{~h}$-starved animals only (Table 3 ).

\section{DISCUSSION}

Glucose infusion has been used previously to study the control of glucose metabolism in ruminants with varying results (Bartley \& Black, 1966; Judson \& Leng, 1973; Lomax et al. 1979; Baird et al. 1980). In male sheep, infusion causes a small decrease in endogenous production which is related to, and equivalent to approximately $25 \%$ of, the rate of supply of the exogenous glucose (Judson \& Leng, 1973). In contrast, lactating cows respond to glucose infusion by decreasing the rate of hepatic and total glucose production substantially but non-lactating cows show little response (Lomax et al. 1979; Baird et al. 1980). In the present study using the fed lactating goats, glucose infusion $(500 \mu \mathrm{mol} / \mathrm{min})$ starting $2 \mathrm{~h}$ after the morning feed and lasting for $4 \mathrm{~h}$ had only a small inhibitory effect on the endogenous rate of irreversible glucose turnover similar to that of fed non-lactating cows and sheep; the mean decrease in the endogenous rate of irreversible glucose turnover during glucose infusion was approximately $14 \%$ (i.e. equivalent to approximately $25 \%$ of the rate of the exogenous supply). This apparent lack of exogenous glucose on gluconeogenesis may arise from the use of propionate as a major glucose precursor in the fed ruminant. There appears to be little control of gluconeogenesis from propionate as Judson \& Leng (1973) have shown that gluconeogenesis from propionate is less effectively suppressed by exogenous glucose than is gluconeogenesis from substrates other than propionate.

The lactating goats starved for $48 \mathrm{~h}$ responded very differently to glucose infusion compared with their fed counterparts. There was a dramatic reduction in the endogenous rate of irreversible glucose turnover to approximately $40 \%$ of the control value in the $48 \mathrm{~h}$ starved lactating goats. This reduction was equivalent to approximately $45 \%$ of the rate of exogenous glucose supply. A similar response in reducing glucose production by approximately $55 \%$ of the rate of exogenous glucose supply is seen during glucose infusion into starved male sheep (West \& Passey, 1967). Despite this decrease in the endogenous rate of irreversible glucose turnover, plasma glucose concentrations increased by approximately $88 \%$ during infusion. The starved lactating goats seemed much less capable of regulating plasma glucose concentrations than their fed counterparts. Similar effects were observed in fed and starved lactating cows (Treacher et al. 1976). This inability to regulate plasma glucose concentrations may be due to an inability to increase peripheral utilization 
in response to the increase in the circulating insulin concentrations which, although elevated during glucose infusion into starved goats, did not reach the concentrations seen in the fed goats infused with glucose.

Rates of milk secretion changed little in response to glucose loading. Glucose infusion starting $2 \mathrm{~h}$ after the morning feed and lasting for $4 \mathrm{~h}$ in fed animals had no effect and, although milk yields were increased by approximately $30 \%$ in the $48 \mathrm{~h}$-starved animals, rates of milk secretion in the glucose-infused starved animals were less than $50 \%$ of those in the fed animals. Thus decreased glucose availability appears to be only a minor factor in reducing milk yields during starvation, and glucose availability may be an important regulator of mild secretion only when values are markedly depressed. However, despite the glucose loading in these starved animals, the total irreversible loss of glucose (mean $628 \mu \mathrm{mol} / \mathrm{min}$ ) was less than that in the fed controls (mean $819 \mu \mathrm{mol} / \mathrm{min}$ ). A greater response in milk production may have been seen if more exogenous glucose had been infused.

The pattern of glucose metabolism in the mammary gland was affected by glucose loading. There was an increased rate of incorporation into lactose in the starved animals corresponding to the increased milk yield. In addition, in both fed and starved animals the amount of glucose metabolized via glycolysis appeared to increase substantially, as the incorporation of glucose into mammary-venous $\mathrm{CO}_{2}$ and milk citrate and triacylglycerol all increased several fold. Similar increases in incorporation of glucose into milk citrate were seen in the cow during glucose loading (Bartley \& Black, 1966). The rate of glucose metabolism via the pentose phosphate pathway also increased as indicated by the increased incorporation of ${ }^{3} \mathrm{H}$ from $\left[3-{ }^{3} \mathrm{H}\right]$ glucose into milk fat $\left({ }^{3} \mathrm{H}\right.$ from $\left[3-{ }^{3} \mathrm{H}\right]$ glucose is transferred to NADPH during metabolism in the pentose phosphate pathway, the NADPH then providing the hydrogen required for fat synthesis). Thus, although glucose loading had no effect on the major pathway of glucose utilization in the mammary gland (i.e. lactose synthesis) in the fed animal, it did result in an increased rate of glucose utilization by some of the minor pathways which, under normal conditions, utilized glucose sparingly. In the $48 \mathrm{~h}$-starved animals, glucose loading stimulated glucose utilization via glycolysis, the pentose phosphate pathway and lactose synthesis.

The reasons for these changes in the pattern of glucose metabolism in the mammary glands of both fed and starved goats are still unknown, but may be related to the hormonal changes (such as the elevation of plasma insulin concentrations) which occur during glucose loading.

The authors thank Mrs H. T. Pollock for expert technical assistance, Dr D. J. Flint for determining insulin concentrations and $\mathrm{Mr} \mathrm{T}$. F. Hutchison for caring for the animals. N.C. was the recipient of a grant from the Faculty of Veterinary Sciences, Chulalongkorn University, Thailand.

\section{REFERENCES}

Annison, E. F., Linzell, J. L. \& West, C. E. (1968). J. Physiol., Lond. 197, 445.

Baird, G. D., Lomax, M. A., Symonds, H. W. \& Shaw, S. R. (1980). Biochem. J. 186, 47.

Bartley, J. C. \& Black, A. L. (1966). J. Nutr. 89, 317.

Bergman, E. N. (1973). Cornell Vet. 63, 341.

Blatchford, D. R. \& Peaker, M. (1982). Q. Jl exp. Physiol. (In the Press.)

Chaiyabutr, N., Faulkner, A. \& Peaker, M. (1980). Biochem. J. 186, 301.

Chaiyabutr, N., Faulkner, A. \& Peaker, M. (1982). Br. J. Nutr. 46, 87.

Judson, G. J. \& Leng, R. A. (1973). Br. J. Nutr. 29, 159.

Linzell, J. L. (1960). J. Physiol., Lond, 153, 481.

Linzell, J. L. (1967). J. Physiol, Lond. 190, 347.

Linzell, J. L. \& Peaker, M. (1971). J. Physiol., Lond. 216, 717. 
Lomax, M. A., Baird, G. D., Mallinson, C. B. \& Symonds, H. W. (1979). Biochem. J. 1800, 281.

Mepham, T. B. \& Linzell, J. L. (1974). J. Dairy Res. 41, 111.

Reid, I. M., Stark, A. J. \& Isenor, R. N. (1977). J. comp. Path. 87, 241.

Rook, J. A. F. (1979). Proc. Nutr. Soc. 38, 309.

Treacher, R. J., Baird, G. D. \& Young, J. L. (1976). Biochem. J. 158, 127.

West, C. E. \& Passey, R. F. (1967). Biochem. J. 102, 58. 